УДК 346.545/546

DOI https://doi.org/10.32837/pyuv.v0i1.729

Ю. O. MoiceEb

orcid.org/0000-0001-6610-9015

кандидат юридичних наук, доиент,

доцент кафедри господарського права

Донецького національного університету ілені Василя Стуса

\title{
ДО ПИТАННЯ ПРАВОВОГО РЕГУЛЮВАННЯ ЕКОНОМІЧНОЇ КОНКУРЕНЦІї У СФЕРІ БІРЖОВОЇ ТОРГІВЛІ
}

Постановка проблеми. Особливу роль в інфраструктурі сучасної ринкової економіки відіграють товарні та фондові біржі, які, працюючи за принципом вільної конкуренції, сприяють спрощенню процесу торгівлі, захисту інтересів продавців та покупців від негативних цінових коливань. При цьому варто звернути увагу, що одним із потужних факторів, які безпосередньо впливають на розбудову та функціонування національного біржового ринку України, є глобалізаційні процеси у світовій економіці.

Маючи багатогранний характер, глобалізація не тільки зумовлює зміну характеру конкуренції, $\mathrm{a}$ й сприяє значному підвищенню агресивності ринкової поведінки учасників біржової торгівлі у процесі конкурентної боротьби. Вказуючи на ці тенденції, О.В. Сидоренко наголошує, що вітчизняним регуляторам і учасникам біржових відносин слід враховувати процеси глобалізації світового ринку, інакше витримати світову конкуренцію вітчизняним інвесторам не вдасться. Для цього слід ліквідувати відставання від провідних фінансових центрів у сфері регулювання, інфраструктури та інструментарію. Невирішення цих проблем призведе до зникнення ознак національного фінансового та товарного біржових ринків [1].

3 огляду на вищенаведене, необхідно як основне завдання розглядати підвищення рівня правового забезпечення процесу формування та розвитку конкурентних відносин у сфері біржової торгівлі, посилення ролі та змісту діяльності біржі як інституціонального елементу побудови конкурентної моделі біржового ринку України, використання антимонопольними органами найбільш ефективних способів захисту прав та інтересів всіх учасників біржової торгівлі від проявів недобросовісної конкуренції.

Аналіз останніх досліджень та публікацій. Дослідженням окремих аспектів правового регулювання діяльності біржі та організації біржової торгівлі було присвячено роботи таких учених-юристів, як О.А. Беляневич, О.М. Вінник, В.С. Деревнін, К.Б. Дудорова, О.Ю. Минюк, Л.Я. Мороз, Л.О. Січко, О.Б. Ткаченко, Ю.В. Чижмарь, B.С. Щербина та інші. Однак, незважаючи на досить грунтовне дослідження окремих аспектів правового регулювання діяльності біржі як суб'єкта господарської діяльності, виникає необхідність наукового осмислення сутності, ролі та змісту регулювання конкуренції на біржовому ринку, проведення комплексних досліджень методологічної основи застосування законодавства про захист економічної конкуренції у сфері біржової торгівлі.

Мета статті - удосконалення нормативно-правового забезпечення та трансформації механізму правового регулювання біржової торгівлі на основі теоретичного та практичного осмислення впливу конкуренції на розвиток правовідносин у сфері біржової торгівлі.

Виклад основного матеріалу. У межах опрацювання питання економічної конкуренції у сфері біржової торгівлі варто підкреслити, що визначальними засадами організації та здійснення діяльності бірж є такі принципи, як рівноправність учасників біржових торгів, застосування вільних (ринкових) цін, публічного проведення біржових торгів. Дотримання та реалізація вказаних принципів стає підгрунтям того, що біржа в реальній економіці має ознаки ринку досконалої конкуренції, тобто ідеальної ринкової структури, коли окремі продавці і покупці не можуть впливати на ціну.

Необхідно підкреслити, що за всієї абстрактності концепції ринку досконалої конкуренції саме ступінь розвитку конкурентних відносин у біржовій торгівлі виступає потужним фактором, який диктує загальні умови функціонування біржового ринку. В цьому контексті важливого значення набуває економічна та юридична оцінка конкурентних відносин на біржовому ринку, яка була надана у низці наукових робіт, присвячених цьому питанню.

Зокрема, В.О. Яворська та О.М. Тягнирядно на підставі аналізу основних результатів біржової торгівлі на міжнародних товарних і фінансових ринках роблять висновок, що міжнародний біржовий ринок в сучасних умовах - це ринок тісної конкуренції між біржовими об'єднаннями. Аналіз рейтингу топ-10 міжнародних бірж свідчить, що до нього увійшли переважно біржові альянси, які утворились у результаті об'єднань та поглинань. На підставі цього зроблено висновок, що посилення конкуренції на міжнародному біржовому ринку продовжує нові поглинання та об’єднання 
і створюе додаткові можливості для біржових учасників [2, с. 237].

M.O. Солодкий звертає увагу, що концентрація біржового обігу є наслідком гострої конкуренції між біржами за учасників торгів. За багатьма товарами конкуренція між біржами триває протягом тривалого часу. Зберіганню однотипних угод на різних біржах сприяє встановлена диференціація товарів, яка призводить до того, що конкуренція не має прямого характеру. Яскравим прикладом цього слугує американський ринок пшениці [3].

Схожу думку висловлює Ю.А. Іщук, який зазначає, що сучасний світовий біржовий ринок стрімко розвивається та впливає на різні сторони ведення господарської діяльності. Відбувається об'єднання міжнародних бірж із метою утворення альянсів для оптимізації введення біржової торгівлі. Фондові і товарні біржі перетворюються на універсальні біржові альянси. Крім того, значно розширюється номенклатура біржових товарів [4, с. 136].

Узагальнюючи вищевказані позиції, слід підкреслити, що наслідком гострої конкуренції між біржами на протязі тривалого часу є концентрація біржового обігу, виникнення біржових альянсів на національному та континентальному рівнях.

Безумовно, посилення конкуренції на міжнародному біржовому ринку має свій прояв також на національному рівні України, що проявляється у концентрації біржової торгівлі певними товарами за регіональними ознаками та віднесенні біржового товару до певної групи товарів. Аргументом на користь такого підходу може слугувати діяльність біржі на ринку газу, що сьогодні розглядається як обов'язковий елемент інфраструктури провідних газових ринків, без якого неможливе існування цивілізованих конкурентних відносин.

Так, на торгах природним газом, що проводить Українська енергетична біржа, беруть участь близько 200 трейдерів та приватних видобувачів газу. За статистичними даними, тільки в 2017 році на біржі було реалізовано 137,1 млн куб. м газу, в 2018 році - 154,2 млн куб. м. На думку спеціалістів, такий крок може стати основою створення в Україні дійсно конкурентного ринку газу [5].

Також у межах опрацювання питання стану конкурентних відносин на біржовому ринку слід враховувати співвідношення загальної кількості бірж в Україні та результати їхньої реальної діяльності щодо організації та здійснення біржової торгівлі. Так, станом на 01.01.2015 р. в Україні було зареєстровано 555 бірж, із них 391 товарно-сировинна, 104 універсальних, 24 агропромислових та 36 інших. При цьому найбільша частка біржових угод $(90,8 \%)$ припадала на біржі, що діють у чотирьох регіонах України: м. Київ $(52,6 \%)$, Полтавській $(25,1 \%)$, Рівненській $(6,6 \%)$ та Дніпропетровській $(6,5 \%)$ областях [6, с. 183]. При цьому, як показує аналіз статистичних даних, найбільший обсяг укладених угод щодо цінних паперів та біржових товарів фактично припадає на дві біржі, а саме Аграрну біржу та АТ «Фондова біржа ПФТС».

Узагальнюючи вищевказане, можна зробити висновок, що формування конкурентного середовища на біржовому ринку України в сучасних умовах господарювання являє собою складний та багатогранний процес, що характеризується концентрацією біржової торгівлі на регіональному рівні та посиленням конкуренції на біржовому ринку. Це потребує забезпечення належного рівня ефективного захисту економічної конкуренції у цій сфері господарювання шляхом внесення кардинальних змін у нормативно-правові акти, що становлять основу правового регулювання організації та здійснення біржової торгівлі.

Сьогодні правову основу біржової торгівлі становлять такі нормативно-правові акти, як Господарський кодекс України (далі - ГК України), Закон України «Про товарну біржу», Закон України «Про цінні папери та фондовий ринок», Закон України «Про захист економічної конкуренції», Закон України «Про захист від недобросовісної конкуренції та інші.

Так, наприклад, відповідно до ст. 1 Закону України «Про захист економічної конкуренції» економічна конкуренція (конкуренція) визначається як змагання між суб'єктами господарювання з метою здобуття завдяки власним досягненням переваг над іншими суб'єктами господарювання, внаслідок чого споживачі, суб'єкти господарювання мають можливість вибирати між кількома продавцями, покупцями, а окремий суб'єкт господарювання не може визначати умови обороту товарів на ринку. При цьому суб'єкти господарювання, органи влади, органи місцевого самоврядування, а також органи адміністративно-господарського управління та контролю зобов'язані сприяти розвитку конкуренції та не вчиняти будьяких неправомірних дій, які можуть мати негативний вплив на конкуренцію [7].

Згідно з частиною другою статті 5 ГК України до конституційних основ правового господарського порядку в Україні віднесено забезпечення державою захисту конкуренції у підприємницькій діяльності, недопущення зловживання монопольним становищем на рину, неправомірного обмеження конкуренції та недобросовісної конкуренції [8].

На підставі комплексного аналізу зазначених нормативно-правових актів можна констатувати, що у національному законодавстві закріплено загальні підходи щодо захисту економічної конкуренції у сфері біржової торгівлі, які в основному грунтуються на нормах конкурентного права і стосуються питань захисту інтересів учасників біржової торгівлі у разі порушення законодавства 
про захист економічної конкуренції. При цьому зазначені норми повною мірою поширюються на біржі як організаторів біржової торгівлі, а також на всіх інших суб’єктів господарювання, які є учасниками біржового ринку (біржові брокери, продавці, покупці та їх представники).

Водночас на рівні спеціальних нормативно-правових актів i, зокрема, Закону України «Про товарну біржу» та Закону України «Про цінні папери та фондовий ринок» немає відповідних норм, які б відображали специфіку правового регулювання конкурентних відносин на біржовому ринку $[9 ; 10]$. Таке положення не тільки свідчить про наявність прогалини на рівні спеціального законодавства, а й вказує на відсутність єдиної цілісної системи правового регулювання конкурентних відносин на біржовому ринку України.

Як наслідок, у практиці біржової торгівлі має місце здійснення систематичних правопорушень конкурентного законодавства як з боку учасників біржової торгівлі, так і з боку самих бірж як безпосередніх організаторів біржової торгівлі. Передусім це стосується порушень конкурентного законодавства, передбачених Законом України «Про захист економічної конкуренції», таких як антиконкурентні узгоджені дії суб'єктів господарювання (ст. 6) та зловживання монопольним (домінуючим) становищем на ринку (ст. 13).

Так, наприклад, Антимонопольним комітетом України було розглянуто справу № 92-рк/к від 04.09.2018 р. про порушення законодавства про захист економічної конкуренції з боку товарної біржі «ХАРКІВАГРОПРОМБІРЖА». У процесі розгляду справи було встановлено, що товарна біржа «ХАРКІВАГРОПРОМБІРЖАА, маючи ознаки монопольного (домінуючого) становища на ринку послуг з організації та проведення аукціонів 3 продажу необробленої деревини на території Харківської області, розробила Регламент організації та проведення аукціону з продажу необробленої деревини, яким було закріплено певні обмеження щодо участі в аукціоні суб'єктів господарювання, які мають намір придбати необроблену деревину лісокористувачів Харківської області для інших потреб, ніж для власного деревообробного виробництва.

На підставі дослідження всіх обставин справи Антимонопольним комітетом України було зроблено висновок, що дії біржі містять ознаки порушення законодавства про захист економічної конкуренції, передбаченого частиною першою статті 13, пунктом 2 статті 50 Закону України «Про захист економічної конкуренції», у вигляді зловживання монопольним (домінуючим) становищем на ринку послуг з організації та проведення аукціонів з продажу необробленої деревини в межах Харківської області, що може призвести до обмеження конкуренції на ринку необробленої деревини, які були б неможливими за умов існування значної конкуренції на ринку [11].

Як було зазначено вище, досить поширеним правопорушенням конкурентного законодавства у сфері біржової торгівлі $€$ антиконкурентні узгоджені дії суб’єктів господарювання. Так, за рішенням адміністративної колегії Кіровоградського обласного територіального відділення Антимонопольного комітету України, дії Кіровоградської Аграрної біржі, ДП «Чорноліський лісгосп», ДП «Олександрівський лісгосп», ТДВ «Інтерресурси» та ТОВ «Світловодський завод пиломатеріалів» під час проведення аукціону з продажу необробленої деревини, який проводився у два етапи, визнано як факт порушення Закону України «Про захист економічної конкуренції», передбачений пунктом 1 статті 50, частини 1 статті 6 та пунктом 4 частини 2 статті 6 Закону України «Про захист економічної конкуренції», у вигляді антиконкурентних узгоджених дій, які призвели до усунення конкуренції та спотворення результатів аукціону. На вищевказаних суб'єктів господарювання накладено штраф на загальну суму 176942 (сто сімдесят шість тисяч дев’ ятсот сорок дві) гривні [12].

У межах опрацювання питання характеристики порушень конкурентного законодавства у сфері біржової торгівлі також становлять інтерес результати моніторингу впливу локальних нормативно-правових актів бірж на стан конкуренції на певному ринку. Зокрема, під час дослідження ринку електроенергії Антимонопольним комітетом України було встановлено, що згідно з Регламентом проведення аукціонів на «Українській енергетичній біржі» виробникам електроенергії було надано можливість укрупнювати лоти шляхом об’єднання їх у крупні пакети. На думку спеціалістів Антимонопольного Комітету України, такий підхід відсікає чимало дрібних покупців, які так само могли би взяти участь у торгах і забезпечити формування справедливої ринкової ціни. Крім цього, за оцінкою Антимонопольного комітету України, такі штучні обмеження в доступі до ресурсів ставлять у нерівні умови різні за розмірами компанії. А це значить, що вони мають ознаки спотворення конкуренції і надання конкурентних переваг одним суб’єктам господарювання над іншими [13].

Беручи до уваги вищеозначене, необхідно підкреслити, що захист прав та законних інтересів всіх учасників конкурентних правовідносин у сфері біржової торгівлі, а також подальший розвиток конкурентного середовища на біржовому ринку потребують застосування комплексного підходу, який передбачає удосконалення механізму правового регулювання конкурентних відносин.

Основою для такого удосконалення повинні стати базові принципи доброчесної конкуренції (принцип рівності, законності, прозорості, відповідальності тощо), а також закріплення у біржо- 
вому законодавстві конкретних правових засобів, які дозволять забезпечити ефективний розвиток економічної конкуренції на біржовому ринку і будуть спрямовані на виявлення (попередження) та припинення порушень конкурентного законодавства або можливостей для їх здійснення.

Розбудова системи злагодженої співпраці та координації між антимонопольними органами та біржами щодо втілення принципів та реалізації положень національної конкурентної політики в Україні у сфері підвищення ефективності захисту економічної конкуренції у сфері біржової торгівлі потребує удосконалення біржового законодавства на основі поєднання публічних та приватних інтересів, що дозволить значною мірою відобразити специфіку конкурентних відносин учасників біржової торгівлі.

Висновки. Підводячи підсумки, потрібно зазначити, що аналіз наукової літератури, норм права, а також практики застосування норм конкурентного законодавства у сфері біржової торгівлі свідчить про таке.

Зміст правових заходів, що можуть позитивно вплинути на розвиток конкурентних відносин у сфері біржової торгівлі, може полягати у проведені антимонопольними органами моніторингу та контролю за дотриманням конкурентного законодавства в процесі організації та здійснення біржової торгівлі.

На рівні спеціального законодавства необхідно передбачити обов' язок товарних та фондових бірж як організаторів біржової торгівлі, які відповідно до законодавства мають особливий правовий статус, погоджувати з Антимонопольним комітетом України положення Правил біржової торгівлі, інших нормативно-правових актів локального характеру як такі, що можуть призвести до недопущення, усунення, обмеження чи спотворення конкуренції на відповідних біржах.

3 урахуванням вищезазначеного пропонується доповнити Закон України «Про товарну біржу» статтею 1-1 «Недопущення обмеження конкуренції у біржовій торгівлі» такого змісту:

1. Товарні біржі здійснюють свою діяльність 3 урахуванням вимог законодавства про захист економічної конкуренції та забезпечують захист учасників біржової торгівлі від недобросовісної конкуренції.

2. Товарні біржі як суб’єкти господарювання зобов'язані сприяти розвитку конкуренції у сфері біржової торгівлі та не вчиняти будь-яких неправомірних дій, які можуть мати негативний вплив на конкуренцію.

3. Свобода конкуренції та забезпечення її сумлінності є основним принципом правового регулювання у сфері біржової торгівлі.

4. Товарна біржа зобов'язана погоджувати 3 Антимонопольним комітетом України, його територіальними відділеннями проекти Правил біржової торгівлі як локальних нормативно-правових актів, що можуть вплинути на конкуренцію, зокрема, щодо встановлення і зміни правил поведінки учасників біржової торгівлі, або такі, що можуть призвести до недопущення, усунення, обмеження чи спотворення конкуренції на відповідному ринку.

Реалізація вищевказаних пропозицій буде певною мірою сприяти реалізації ключових принципів захисту економічної конкуренції, створенню конкурентного середовища на біржовому ринку та ефективному функціонуванню сучасних конкурентних моделей організації та ведення біржової торгівлі в Україні.

\section{Jimepamypa}

1. Сидоренко О.В. Консолідація біржової системи як фактор підвищення іï конкурентноздатності. Ефективна еконоліка. 2011. № 11. URL: http://www. economy.nayka.com.ua/ lfnf (дата звернення 05.03.2021р.).

2. Яворська В.О., Тягнирядно О.М. Біржова торгівля на міжнародних товарних і фінансових ринках. Еконоліка і суспільство. 2018. № 18. С. 236-240.

3. Солодкий O.М., Гниляк В.О. Біржовий ринок США: стан та перспективи розвитку. Ефективна економіка. 2010. № 10. URL: http://www.economy. nayka. com.ua/ (дата звернення 10.03.2021р.).

4. Іщук Ю.А. Товарна біржа як інституціональний елемент функціонування міжнародних товарних ринків. Еконоліка і організація управління. 2017. № 3. C. 135-142.

5. Досягнення Української енергетичної біржі у 2018 році. URL: https://www.ueex.com.ua/ (дата звернення 08.03.2021 p)

6. Вавдійчик I.M. Сучасний стан та тенденції розвитку біржової торгівлі в Україні. Глобальні та наиіональні проблели еконоліки. 2017. №15. С.182-185.

7. Про захист економічної конкуренції: Закон України від 11 січня 2001 р. № 2210-III. Відомості Верховної Ради України. 2001. № 12. Ст. 64. (Із змінами).

8. Господарський кодекс України: Закон України від 16 січня 2003 р. № 436-IV. Відомості Верховної Ради Украйни. 2003. № 18-22. Ст. 144. (Із змінами).

9. Про товарну біржу: Закон України від 10 грудня 1991 р. № 1956-XII. Відолості Верховної Ради України. 1992. № 10. Ст. 139. (Із змінами).

10. Про цінні папери та фондовий ринок: Закон України від 23.02.2006 р. № 3480-IV. Відолості Верховної Ради України. 2006.№ 31. Ст. 268 (Із змінами).

11. Щодо припинення дій, які містять ознаки порушення законодавства про захист економічної конкуренції. Рекомендації Адміністративної колегії Харківського обласного територіального відділення Антимонопольного комітету України від 04.09.2018 № 92-pк/к. URL: http://www.amc.gov.ua (дата звернення 25.03.2021 р.)

12. Верховний суд підтвердив правильність рішення КОТВ АМКУ у справі про антиконкурентні узгоджені діï. URL: http://www.amc.gov.ua (дата звернення 09.03.2021 р.)

13. Щодо здійснення заходів спрямованих на запровадження біржової торгівлі електроенергією. Лист Антилонопольного комітету України № 128-29/02 від 19.04.2018 p. URL: https://amcu.gov.ua (дата звернення 21.03.2021 p.) 


\section{Анотація}

Моісєєв Ю. О. До питання правового регулювання економічної конкуренції у сфері біржової торгівлі. - Стаття.

У статті проведено аналіз впливу процесів глобалізації та концентрації на розвиток біржового ринку України, акцентовано увагу на посилення конкуренції серед учасників біржової торгівлі в сучасних умовах ринкової економіки.

На підставі аналізу різних думок, висловлених ученими-економістами та юристами, зроблено висновок про необхідність розглядати як першочергове завдання удосконалення правового забезпечення процесу формування та розвитку конкурентних відносин у сфері біржової торгівлі.

Автором досліджено особливості формування правової основи захисту економічної конкуренції у сфері біржової торгівлі, наведені приклади та надана змістовна характеристика таких видів правопорушень конкурентного законодавства, як зловживання монопольним становищем та антиконкурентні узгоджені діі суб'єктів господарювання під час проведення біржових торгів.

У статті проведено аналіз практики антимонопольних органів щодо виявлення та попередження порушень конкурентного законодавства у сфері біржової торгівлі шляхом проведення моніторингу біржового ринку, застосування до правопорушників відповідних санкцій, а також надання рекомендацій щодо усунення наслідків правопорушення.

Пропонується удосконалення механізму правового регулювання конкурентних відносин учасників біржової торгівлі на основі побудування системи злагодженої співпраці та координації між антимонопольними органами та біржами щодо втілення принципів та реалізації положень національної конкурентної політики в Україні.

На підставі дослідження обгрунтовано положення щодо необхідності правового закріплення у біржовому законодавстві спеціальних норм, присвячених регулюванню конкурентних правовідносин у сфері біржової торгівлі, як ключової засади формування та розвитку конкурентної моделі біржового ринку України.

Ключові слова: економічна конкуренція, біржа, правове регулювання, правовідносини, біржова торгівля, біржовий ринок.

\section{Summary}

Moisieiev Iu. $O$. To the issue of legal regulation of economic competition in the exchange trade field. - Article.

The article analyses the influence of globalization and concentration processes on the development of the stock market of Ukraine, the accent is made on the strengthening of competition among the participants of exchange trade in modern conditions of the market economy.

Based on the analyses of different points of view of economists and lawyers, the conclusion is made that it is necessary to consider the improvement of legal support of the process of formation and development of competitive relations in the field of exchange trade as a priority.

The author studies the peculiarities of the formation of the legal basis for the protection of economic competition in the field of exchange trade, gives examples and provides a meaningful characteristics of such types of competition law offenses as abuse of monopoly position and anticompetitive concerted actions of economic entities in stock trading.

The article analyses the practical experiences of antimonopoly agencies concerning the detection and preventing of competitive law offenses in the field of exchange trade by monitoring the stock market, applying appropriate sanctions to offenders, as well as providing recommendations to eliminate the consequences of the offense.

It is proposed to improve the mechanism of legal regulation of competitive relations of exchangetrade participants on the basis of building a system of harmonious cooperation and coordination between antimonopoly agencies and exchanges on the implementation of principles and realization of national competition policy in Ukraine.

Based on the study, the provisions on the need for legal securing in the exchange legislation of special rules on the regulation of competitive legal relations in the field of exchange trade as a key basis for the formation and development of a competitive model of the exchange market of Ukraine are substantiated.

Key words: economic competition, exchange, legal regulation, legal relations, exchange trade, stock market. 